\title{
Sugarcane micropropagation using light emitting diodes and adjustment in growth-medium sucrose concentration
}

\author{
Micropropagação de cana-de-açúcar com diodos emissores de luz e ajuste da concentração \\ de sacarose do meio de cultivo
}

\author{
Paulo Sérgio Gomes da Rocha ${ }^{\mathrm{I}}$ Roberto Pedroso de Oliveira ${ }^{\mathrm{I}}{ }^{*}$ Walkyria Bueno Scivittaro ${ }^{\mathrm{II}}$
}

\begin{abstract}
The aim of this research was to evaluate the use of light emitting diodes (LEDs) instead of white fluorescent lamps as light source and adequate growth-medium sucrose concentration for sugarcane micropropagation (Saccharum officinarum L.). Sugarcane (RB 872552 variety) bud explants were evaluated during the multiplication and rooting phases under controlled growth-room conditions. Different light sources (blue, red and green LEDs; Growlux and white fluorescent lamps) and different medium sucrose concentrations $\left(0 ; 15 ; 30\right.$ and $\left.45 \mathrm{~g} \mathrm{~L}^{-1}\right)$ were used, maintaining constant light intensity $\left(20 \mu \mathrm{mol} \mathrm{m} \mathrm{m}^{-2} \mathrm{~s}^{-1}\right)$, photoperiod (16h) and temperature $\left(25 \pm 2^{\circ} \mathrm{C}\right)$. The experiment was a completely randomized design, and treatments were arranged in a $5 \times 4$ factorial (five light sources and four medium sucrose concentrations) with six replications. Sugarcane bud growth was satisfactory under the three LED types studied. The presence of sucrose in growth media was essential for bud multiplication and rooting. Nevertheless, each light source requires the respective medium sucrose concentration adjustment for best results. Red LEDs provided a significantly high multiplication rate (although not the highest) with 8.5 buds per sub-culture and $34.9 \mathrm{~g} \mathrm{~L}^{-1}$ of sucrose; also, the highest bud length $(33.3 \mathrm{~mm})$ and the best plantlet acclimatization. Therefore, LED sources can advantageously substitute fluorescent lamps in laboratories of sugarcane micropropagation.
\end{abstract}

Key words: Saccharum officinarum, LED, light source, tissue culture, white fluorescent lamp.

\section{RESUMO}

$O$ objetivo deste trabalho foi avaliar o uso de diodos emissores de luz (LEDs) em substituição a lâmpadas fluorescentes brancas e adequar a concentração de sacarose na micropropagação de cana-de-açúcar (Saccharum officinarum L.). Brotações da variedade $R B 872552$ foram avaliadas nas fases de multiplicação e enraizamento, utilizando as fontes de luz LEDs azuis, LEDs vermelhos, LEDs verdes, lâmpadas Growlux e lâmpadas fluorescentes brancas, e as concentrações de sacarose de 0, 15, 30 e $45 \mathrm{~g} \mathrm{~L}^{-1}$, fixando-se a intensidade luminosa em $20 \mu \mathrm{mol} \mathrm{m}^{-2} \mathrm{~s}^{-1}$. Os tratamentos foram dispostos em delineamento inteiramente ao acaso, em fatorial $5 \times 4$ (fontes de luz $x$ concentrações de sacarose). O desenvolvimento das brotações foi satisfatório sob os três tipos de LEDs estudados. A presença de sacarose no meio de cultivo foi indispensável para multiplicação e enraizamento das brotações, sendo necessário ajuste da concentração para cada fonte de luz. Os LEDs vermelhos não proporcionaram a maior taxa de multiplicação, porém esta foi bastante alta $\left(8,5\right.$ brotos por subcultivo, com adição de $34,9 \mathrm{~g} \mathrm{~L}^{-1}$ de sacarose), com maior comprimento dos brotos $(33,3 \mathrm{~mm})$ e maior eficiência de aclimatização das plantas. Concluiu-se que os LEDs podem ser utilizados como substitutos das lâmpadas fluorescentes em laboratórios de micropropagação de cana-de-açúcar.

Palavras-chave: Saccharum officinarum, LED, fonte de luz, cultura de tecidos, lâmpada fluorescente branca.

\section{INTRODUCTION}

Sugarcane (Saccharum officinarum L.) is one of the most important crops in Brazil, providing several valuable products and subproducts, such as sugar, ethanol and electricity. Brazil is the first largest world sugarcane producer country, with an estimated annual production of 690 millions of tons produced in approximately four million hectares (FAO, 2012). Among the several available sugarcane varieties, RB 872552 is pointed out as a high tillering variety, presenting low demand for nutrients, low plant flowering rate, early maturation, low fiber content and high yields for both agricultural and industrial interests (SIMÕES NETO et al., 2005).

Sugarcane in vitro propagation has been routinely used in Brazil, in order to produce healthy

\footnotetext{
'Universidade Regional Integrada do Alto Uruguai e das Missões (URI), Erechim, RS, Brasil.

IEmbrapa Clima Temperado, 96001-970, Pelotas, RS, Brasil. E-mail: roberto.pedroso@embrapa.br. *Autor para correspondência.
}

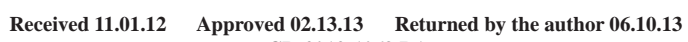


plantlets from new improved cultivars, which can be more readily available to farmers. Although the Saccharum officinarum is a highly responsive in vitro species, since it is possible to obtain 200 thousand plantlets per year from one single explant source, high scale sugarcane plantlet micropropagation has been limited by the production costs (JALAJA et al., 2008).

The white fluorescent lamps, associated or not to natural illumination and/or to Growlux lamps, have been used as light source in practically all tissue culture laboratories (ROCHA et al., 2010). This light source is responsible, in average, for $65 \%$ of the total laboratory energy costs (ERIG \& SCHUCH, 2005). During the last years, light emission diodes (LEDs) have been the newness in the ambient illumination market. LEDs main advantages are the low heat generation and high light efficiency, long life period, specific wavelength and little mass and volume (YEH \& CHUNG, 2009). Besides the electric power savings, LEDs may improve in vitro bud development by choosing the specific optimal photosynthesis wavelengths (ROCHA et al., 2010). However, there is no information on the subject for sugarcane, although significant positive results were obtained with this new light source in other plant species.

Plant species are autotrophic, but most of them do not express such property when cultivated in vitro, due to the low $\mathrm{CO}_{2}$ supply and low gas exchange inside the culture flask, and also, to the low light quality and intensity (KOZAI et al., 2005). Therefore, sucrose is one of the main components of culture medium and it is the energy source for developing plantlets. On the other hand, excess of sucrose concentrations in the culture media might cause cellular dehydration by osmotic gradient and higher fungi/bacterial explant contamination (PÉREZ et al., 2004).

The objective of this research was to evaluate the advantages of light emission diodes (LEDs) as an alternative light source for sugarcane micropropagation, and the respective adjustment of sucrose concentration in the culture medium.

\section{MATERIAL AND METHODS}

Sugarcane buds (RB 872552 variety) were the initial explants used in this study, in each 30 day-subculture, with MS medium (MURASHIGE \& SKOOG, 1962) and without addition of growth regulators, under controlled temperature and light growth conditions, with white fluorescent light.

The explants in vitro development was studied during the multiplication and rooting phases. The experiment consisted of a completely randomized design, arranged in a $5 \times 4$ factorial (five sources of light and four sucrose concentrations), with six replications. The experimental unity consisted of one flask containing five explants. The sucrose concentrations in the culture medium were $0 ; 15 ; 30$ and $45 \mathrm{~g} \mathrm{~L}^{-1}$; and the light sources used in the growth room were: blue light emitting diodes (LEDs) EDEB3LA1 470nm, green LEDs-3LA1 530nm, red LEDsEDER 3LA3 630nm, Growlux fluorescent lamps and white fluorescent lamps. Light intensity during explant growth was maintained constant at $20 \mu \mathrm{mol} \mathrm{m} \mathrm{m}^{-2} \mathrm{~s}^{-1}$.

The multiplication phase was studied with explants of $20 \pm 3 \mathrm{~mm}$ length grown in $250 \mathrm{~mL}$ flasks containing $40 \mathrm{~mL}$ of semi-solid MS medium with the addition of $100 \mathrm{mg} \mathrm{L}^{-1}$ of myo-inositol; $0.3 \mathrm{mg} \mathrm{L}^{-1}$ of 6-benzilaminopurine (BAP) and $7 \mathrm{~g} \mathrm{~L}^{-1}$ of agar, during three subsequent 30 day-subcultures. The culture medium $\mathrm{pH}$ was adjusted to 5.8 , before the sterilization at $121^{\circ} \mathrm{C}$ and $1.5 \mathrm{~atm}$ for 20 minutes. Temperature and photoperiod were maintained constant at $25 \pm 2^{\circ} \mathrm{C}$ for 16 hours, respectively. The three 30 -day subculture average data constituted the data for statistical analysis. The bud number and length per explant were the variable means statistically evaluated.

The rooting phase study was carried out with 30 mm-length buds selected after the multiplication phase, grown for just one 30-day period in MS medium with the addition of $100 \mathrm{mg}$ $\mathrm{L}^{-1}$ of myo-inositol, $0.3 \mathrm{mg} \mathrm{L}^{-1}$ of indoleacetic acid (IAA) and $7 \mathrm{~g} \mathrm{~L}^{-1}$ of agar, and $\mathrm{pH}$ adjusted to 5.8 . During this phase, the same earlier growth conditions of light and temperature were used. The rooted bud percentage and average root number per explant were the variables statistically evaluated.

After the in vitro rooting phase, rooted plantlets were rinsed in tap water to remove the medium culture residues and transplanted to 72 cell-trays (of expanded polystyrene) containing pine bark substrate, arranged over workbenches in the greenhouse. The trays were maintained under a plastic tunnel, which was gradually and carefully opened just to irrigate according the plant needs. This experiment was a completely randomized design, with 10 replications per light source, and the experimental unit consisted of five plants (sucrose concentration was not considered in this trial). After 20 days of growth, the following variables were evaluated: plantlet surviving percentage, plantlet length including the longest leaf; stem diameter $(1 \mathrm{~cm}$ above plantlet colon); and leaf number.

The results of each growth phase were submitted to analysis of variance (test F, 0.05), and mean comparisons for light source treatments were made by Duncan's test (0.05); and for sucrose concentration treatments by polynomial regression.

Ciência Rural, v.43, n.7, jul, 2013. 
The data related to surviving percentage and rooting percentage were transformed in arc sen $(x / 100)^{1 / 2}$; the bud number and root number were transformed in $(\mathrm{x}+0.5)^{1 / 2}$; and plantlet length, leaf number and plantlet diameter data were not transformed.

\section{RESULTS AND DISCUSSION}

Significant interactions among variables within treatments - sources of light and sucrose concentrations - were determined in both multiplication and rooting phase experiments. Quadratic response curves to sucrose concentrations were observed for sugarcane bud number and length in the multiplication phase under most light sources studied, except for blue and green LEDs. Under these lights, linear responses were observed for bud number (Figure 1). The highest bud number per explant and per subculture was estimated for the sucrose concentration of $34.9 \mathrm{~g} \mathrm{~L}^{-1}$ under red LEDs (8.5 buds); $31.7 \mathrm{~g} \mathrm{~L}^{-1}$ under Growlux lamps (14.7 buds); and $30.9 \mathrm{~g} \mathrm{~L}^{-1}$ under white fluorescent lamps (11.6 buds). As concerned to the culture linear response to blue and green LEDs, the highest bud numbers (11.7 and 11.8 , respectively) were found with $45 \mathrm{~g} \mathrm{~L}^{-1}$ of sucrose. Therefore, in this experiment, the optimized bud number varied from 8.5 to 14.7 depending on the light source, evidencing the adequate adjustment between light source and sucrose concentration for sugarcane micropropagation, since values between 6 and 10 buds have been reported in the literature (JALAJA et al., 2008).

The optimal sucrose concentrations found for sugarcane bud number per explant grown under red LEDs, Growlux lamps and white fluorescent lamps were very close to the usually recommended MS medium sucrose concentration $\left(30 \mathrm{~g} \mathrm{~L}^{-1}\right)$, which is also recommended for micropropagation of several other species: pineapple (Ananas comosus) (PÉREZ et al., 2004); and banana plant (ARAGÓN et al., 2009). Nevertheless, under blue and green LEDs, higher sucrose concentration $\left(>45 \mathrm{~g} \mathrm{~L}^{-1}\right)$ was necessary to obtain optimal explant multiplication rate, corroborating the results observed by KHAN et al. (2006) for other sugarcane varieties.

Independently of light source, there was no explant multiplication without sucrose in the culture medium: control plants were dead before the end of the first 30 day-subculture. Such result demonstrated the heterotrophic sugarcane behavior when grown in vitro, that is, this species explants require sucrose as source of carbon and energy for cell growth and development (KOSAI et al., 2005). On the other hand, species like rabbit-eye blueberry - Vaccinium ashei (DAMIANI \& SCHUCH, 2009) and the orchid Caularthron bicornutum (PIVETTA et al., 2010) are able to survive without sucrose in the culture medium and to multiply under low sucrose concentrations, evidencing their mixotrophic nature.

As concerned to the explant bud length grown in vitro, the best sucrose concentrations were $33.9 \mathrm{~g} \mathrm{~L}^{-1}$ under blue LEDs $(28.4 \mathrm{~mm}) ; 36.4 \mathrm{~g} \mathrm{~L}^{-1}$ under green LEDs $(29.6 \mathrm{~mm}), 35.2 \mathrm{~g} \mathrm{~L}^{-1}$ under red LEDs $(33.3 \mathrm{~mm}), 31.6 \mathrm{~g} \mathrm{~L}^{-1}$ under Growlux lamps (26.6mm); and $31.9 \mathrm{~g} \mathrm{~L}^{-1}$ under white fluorescent lamps $(26.2 \mathrm{~mm})$ (Figure 1). Therefore, the optimal sucrose concentrations for bud length varied between 31.6 to $33.9 \mathrm{~g} \mathrm{~L}^{-1}$, depending on the light source, and those were also very close to the MS medium sucrose concentration. The average bud length obtained $(\sim 30 \mathrm{~mm})$ in all treatments is considered adequate for the rooting phase, because shorter lengths usually restrict plantlet surviving (JALAJA et al., 2008).

Under optimal sucrose concentration, the highest and lowest explant multiplication rates were observed under Growlux lamps and red LEDs, respectively, with intermediary results for the blue and green LEDs and white fluorescent lamps. On the other hand, higher bud lengths were obtained under red, green and blue LEDs than under Growlux and white fluorescent lamps (Figure 1). Such results evidenced the need for reconsidering the generalized use of white fluorescent lamps in tissue culture growth-rooms; because, besides the high explant multiplication rates and adequate bud lengths for the rooting phase obtained under LEDs, these light sources showed also the particular advantage of long average useful life (up to 100,000hours), compared to fluorescent lamps $(8,000$ hours) (YEH \& CHUNG, 2009). Yet, LEDs are free of toxic substances (like mercury) and present high light conversion efficiency, saving power (ROCHA et al., 2010). Although red LEDs provided lower bud number with optimal sucrose concentration (8.5 buds per subculture), such as high multiplication rate when compared to other values reported by sugarcane research works (JALAJA et al., 2008); also, red LEDs provided the longest average bud length $(33.3 \mathrm{~mm})$, considered adequate for the next phase, avoiding the need for a extra elongation period before the rooting phase. The positive effect of LEDs on plant micropropagation, particularly the red LEDs, was already observed in strawberries by ROCHA et al. (2010). According to these authors, the red light spectrum is close to the maximum chlorophyll and phytochromes light absorption peaks; for this reason, red light is important for the photosynthetic apparatus and starch accumulation, enhancing bud development. 


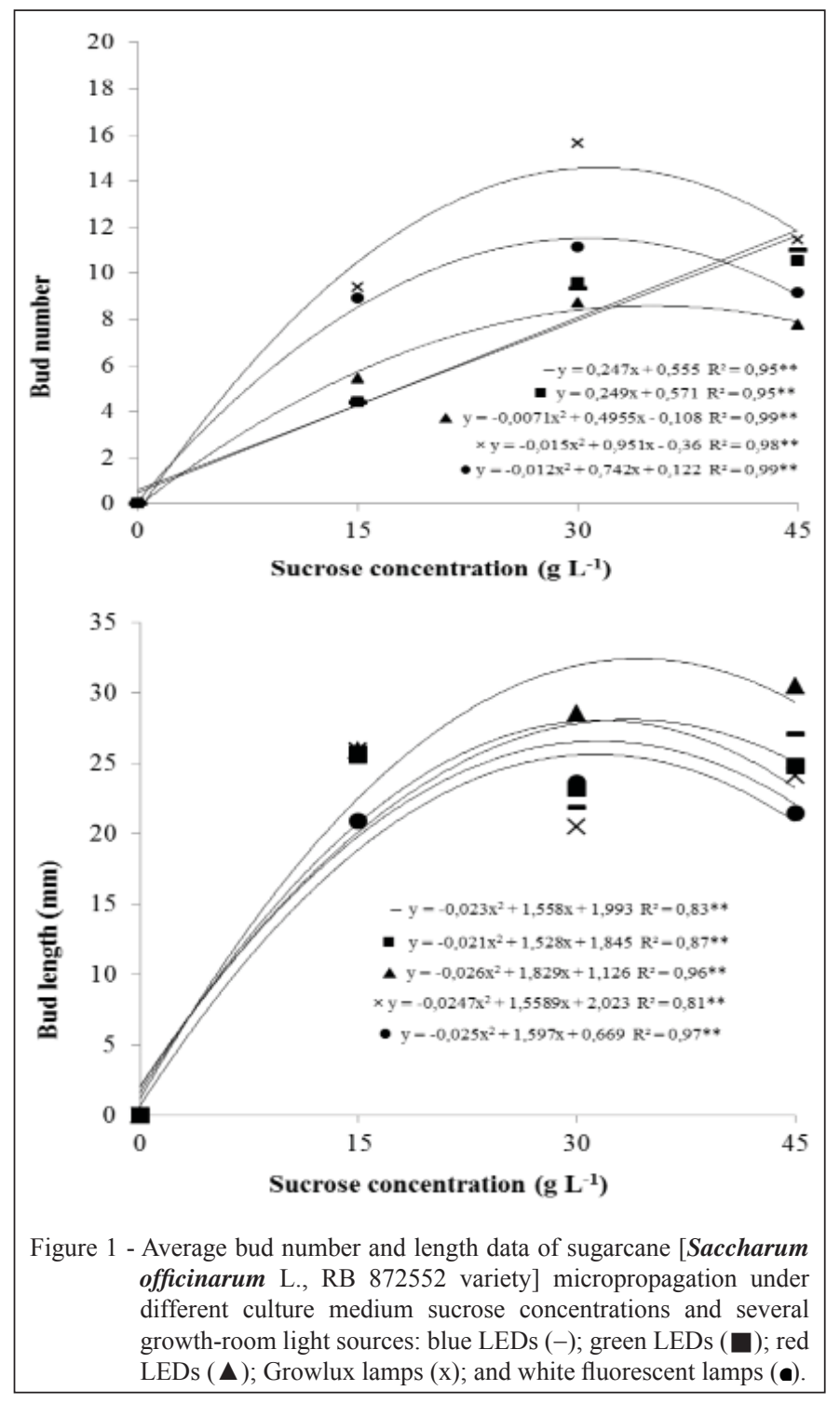

During the rooting phase, quadratic curves were observed for rooted bud (\%) and root number in response to increasing sucrose concentrations, under the light sources studied; except for root number under red LEDs that showed linear response to sucrose concentrations (Figure 2). The highest rooted bud percentages were observed in cultures under red LEDs, blue LEDs and white fluorescent lamps, with $100 \%$ rooted buds for the estimate sucrose concentrations of 32.1 ; 33.6; and $35.2 \mathrm{~g} \mathrm{~L}^{-1}$, respectively. And the highest average root numbers per bud were obtained under red (13.8 roots) and blue LEDs $(9.5$ roots). The fact that red-LEDs induced longer bud root length was certainly the reason for the well-succeeded rooting process. NHUT et al. (2003) had already reported higher strawberry root fresh matter in cultures under red LEDs.

Independently of light sources, there was no rooting in the control without sucrose, evidencing its importance as source of energy for the rhizogenesis process in sugarcane micropropagation. Therefore, in this experiment, buds maintained the heterotrophic characteristic during the in vitro rooting process, corroborating earlier reports of SINGH et al. (2001). Although the optimal sucrose concentration for rooting induction varied with the light source in this study, the literature has also recommended a diversity of sucrose concentrations (all tending to high rates) for sugarcane culture medium. Thus, GOEL et al. (2010) recommended $50 \mathrm{~g} \mathrm{~L}^{-1}$ of sucrose and SINGH et al.

Ciência Rural, v.43, n.7, jul, 2013. 


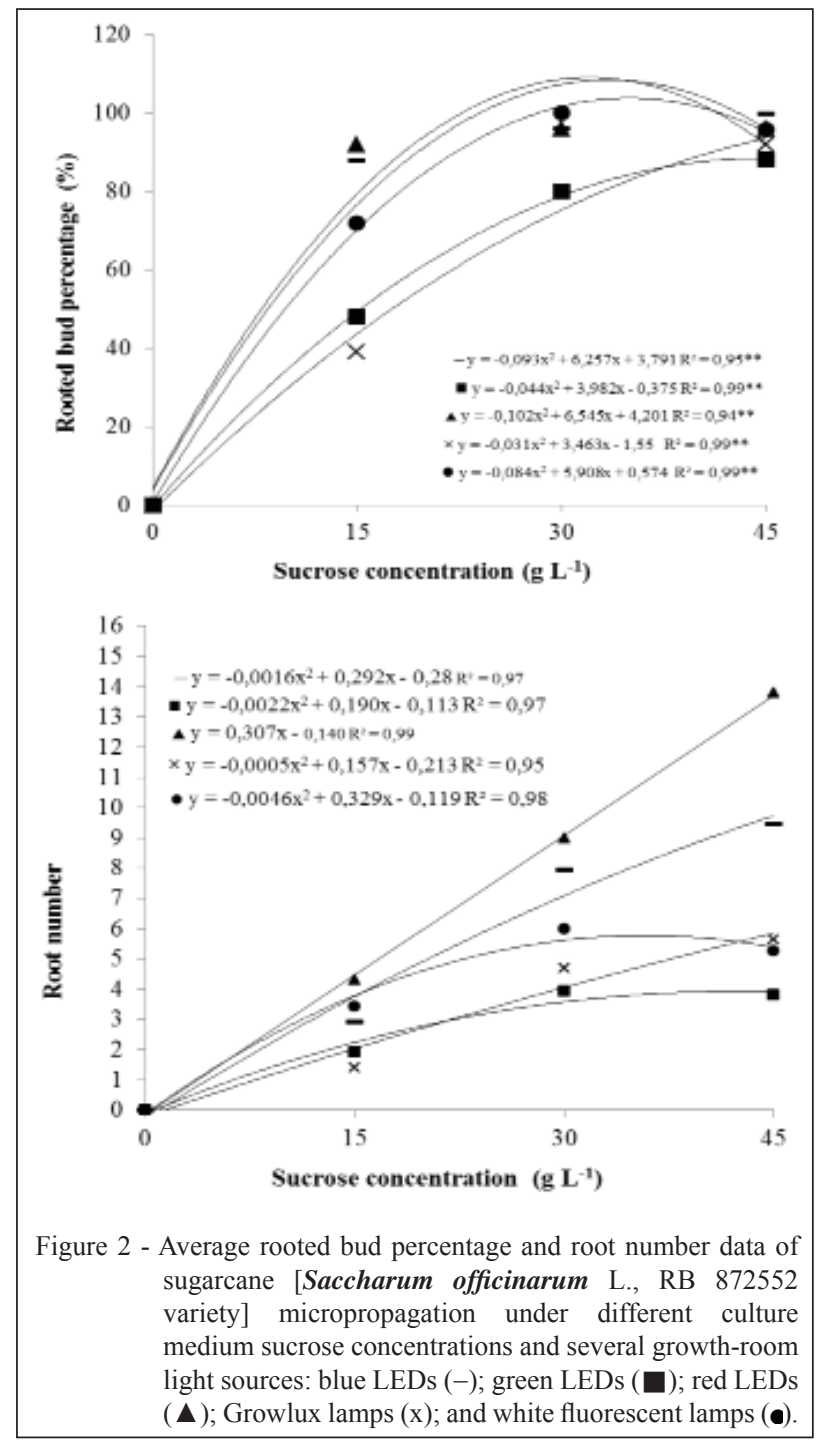

(2001) and KHAN et al. (2006), 60g L $\mathrm{g}^{-1}$ of sucrose in the culture medium, in order to optimize adventitious root growth induction. The fact that lower sucrose concentrations are required for rhizogenesis $(30 \mathrm{~g}$ $\mathrm{L}^{-1}$ ) under red and blue LEDs, it might suggest that plantlets are doing partial photosynthesis, that is, they are in mixotrophic stadium under such conditions.

During the acclimatization of rooted plantlets grown under red LEDs, higher surviving percentage values of transplanted plantlets were observed, and also, longer bud length, higher leaf number and larger bud diameter, following the same rhizogenesis process tendency. The worst performance was observed for plantlets grown under green LEDs (Table 1). Generally, under all sources of light and independently of growth medium sucrose concentration, high surviving percentage rates of acclimatized plantlets were observed in this experiment $(92.3 \%$ to $100 \%)$ similar to the values reported by JALAJA et al. (2008) (95\%) for sugarcane, indicating good adjustment of growth conditions and acclimatization.

\section{CONCLUSION}

Light emission diodes (LEDs) can be potentially advantageous substitutes of white fluorescent lamps in sugarcane micropropagation. The best in vitro plantlet rooting and acclimatization can be provided by red LEDs. The sucrose presence in culture medium is vital for the sugarcane bud multiplication and rooting, but the medium sucrose concentration must be adjusted according to the source of light used. 
Table 1 - Sugarcane [Saccharum officinarum L., RB 872552 variety] bud development observed after in vitro rooting under different light sources and 20 day-acclimatization ${ }^{(1)}$.

\begin{tabular}{|c|c|c|c|c|}
\hline Light source & Surviving $(\%)^{(2)}$ & Bud length $(\mathrm{cm})$ & Bud diameter $^{(3)}(\mathrm{mm})$ & Leaf number \\
\hline Red LEDs & $100.0 \mathrm{a}$ & $38.8 \mathrm{a}$ & $2.4 \mathrm{a}$ & $6.7 \mathrm{a}$ \\
\hline Blue LEDs & $94.6 \mathrm{bc}$ & $21.2 \mathrm{c}$ & $2.0 \mathrm{a}$ & $6.5 \mathrm{ab}$ \\
\hline Green LEDs & $92.3 \mathrm{c}$ & $19.2 \mathrm{~d}$ & $1.6 \mathrm{c}$ & $5.7 \mathrm{c}$ \\
\hline Growlux lamps & $99.9 \mathrm{a}$ & $37.5 \mathrm{a}$ & $2.1 \mathrm{~b}$ & $6.6 \mathrm{ab}$ \\
\hline White fluorescent lamps & $99.6 \mathrm{a}$ & $35.6 \mathrm{~b}$ & $1.6 \mathrm{c}$ & $6.2 \mathrm{bc}$ \\
\hline $\mathrm{CV}(\%)$ & 14.0 & 8.9 & 12.6 & 3.6 \\
\hline
\end{tabular}

${ }^{(1)}$ Means followed by the same small letters in the column do not differ by Duncan's test $(\mathrm{P}<0.05)$.

${ }^{(2)}$ Bud diameter was transformed to $(\mathrm{x}+0.5)^{1 / 2}$ for the analysis of variance.

${ }^{(3)}$ Bud surviving percentage was transformed to $\operatorname{arc} \operatorname{sen}(x+0.5)^{1 / 2}$ for the analysis of variance.

\section{REFERENCES}

ARAGÓN, C.E. et al. Effect of sucrose, light, and carbon dioxide on plantain micropropagation in temporary immersion bioreactors. In Vitro Cellular and Developmental Biology, v.46, p.89-94, 2009. Available from: <http://www.springerlink.com/content/ v415687371722177/fulltext.pdf $>$. Accessed: Oct. 28, 2012. doi: 10.1007/s11627-009-9246-2.

DAMIANI, C.R.; SCHUCH, M.W. Enraizamento in vitro de mirtilo em condições fotoautotroficas. Ciência Rural, v.39, n.4, p.1012-1017, 2009. Available from: <http://www.scielo.br/pdf/cr/ v39n4/a137cr926-1.pdf>. Accessed: Aug. 24, 2012.

ERIG, A.C.; SCHUCH, M.W. Tipo de luz na multiplicação in vitro de framboeseira. Revista Brasileira de Fruticultura, v.27, n.3, p.488-490, 2005. Available from: <http://www.scielo. br/scielo.php? pid $=$ S0100-29452005000300035\& script $=$ sci arttext $>$. Accessed: Jun. 28, 2012. doi: org/10.1590/S010029452005000300035.

FAO (FOOD AND AGRICULTURE ORGANIZATION). Faostat Available from: <http://faostat.fao.org/site/567/DesktopDefault aspx?PageID=567\#ancor $>$. Accessed: Jul. 04, 2012.

GOEL, Y. et al. In vitro morphogenesis in leaf sheath explants of sugarcane hybrid var. CoS 99259. Sugar Tech, v.12, n.2, p.172175, 2010. Available from: $<$ https://springerlink3.metapress.com/ content/mm3r92pp1g67v584/resource-secured/?target=fulltext.pd $\mathrm{f} \& \mathrm{sid}=\mathrm{yvinf} 1 \mathrm{vsg}$ vyulhoznlxw3 $\mathrm{fdr} \& \mathrm{sh}=\mathrm{www}$. springerlink.com $>$. Accessed: Oct. 20, 2012. doi: 10.1007/s12355-010-0033-5.

JALAJA, N.C. et al. Micropropagation for quality seed production in sugarcane in Asia and the Pacific. Rome: FAO, 2008. 46p. Available from: <http://www.apcoab.org/uploads/ files/1279706285sugar_pub.pdf>. Accessed: Jun. 28, 2012.

KHAN, I.A. et al. Effect of sucrose and growth regulators on the micropropagation of sugarcane clones. Pakistan Journal of Botany, v.38, n.4, p.961-967, 2006. Available from: <http://www pakbs.org/pjbot/PDFs/38(4)/PJB38(4)0961.pdf>. Accessed: Oct. $08,2012$.

KOZAI, T. et al. Photoautotrophic (sugar-free medium) micropropagation systems for large-scale commercialization. Propagation of Ornamental Plants, v.5, n.1, p.23-34, 2005 Available from: <http://www.journal-pop.org/References/ Vol_5_1(23-34).pdf>. Accessed: Oct. 18, 2012.
MURASHIGE, T.; SKOOG, F. A revised medium for rapid growth and bioassays with tobacco tissue cultures. Physiologia Plantarum, v.15, p.473-497, 1962. Available from: <http:// garfield.library.upenn.edu/classics 1978/A1978FR51700002.pdf>. Accessed: Fev. 28, 2012.

NHUT, D.T. et al. Responses of strawberry plantlets cultured in vitro under super bright red and blue light-emitting diodes (LEDs). Plant Cell, Tissue and Organ Culture, v.73, p.43-52, 2003. Available from: <http://www.deepdyve.com/lp/springer-journals/ responses-of-strawberry-plantlets-cultured-in-vitro-undersuperbright-p02kb4pH8u>. Accessed: Jun. 18, 2012.

PÉREZ, A. et al. Effect of sucrose, inorganic salts, inositol, and thiamine on protease excretion during pineapple culture in temporary immersion bioreactors. In Vitro Cellular Developmental Biology Plant, v.40, n.3, p.311-316, 2004. Available from: $<$ http://www.jstor. org/discover $/ 10.2307 / 4293743$ ?uid=3737664\&uid=2129\&uid=2\&ui $\mathrm{d}=70 \&$ uid $=4 \&$ sid $=21101308557541>$. Accessed: Oct. 03, 2012.

PIVETTA, K.F.L. et al. Crescimento in vitro de plântulas de Caularthron bicornutum em diferentes concentrações de sacarose. Ciência Rural, v.40, n.9, p.1897-1902, 2010. Available from: <http://www.scielo.br/pdf/cr/2010nahead/a718cr3023.pdf >. Accessed: Oct. 02, 2012.

ROCHA, P.S.R. et al. Diodos emissores de luz e concentrações de BAP na multiplicação in vitro de morangueiro. Ciência Rural, v.40, n.9, p.1922-1928, 2010. Available from: <http://www.scielo.br/ scielo.php? script $=$ sci arttext\&pid $=$ S0103-84782010000900011>. Accessed: Oct. 28, $2012 . \quad$ doi: org/10.1590/S010384782010000900011 .

SINGH, B. et al. An efficient protocol for micropropagation of sugarcane using shoot tip explants. Sugar Tech, v.3, n.3, p.113116, 2001. Available from: <https://springerlink3.metapress.com/ content/9236n216v8r03212/resource-secured/?target=fulltext.pd $\mathrm{f} \& \mathrm{sid}=2 \mathrm{zmilt} 0$ eiaa2 eol2yjqkj4zf\&sh=www.springerlink.com $>$. Accessed: Oct. 28, 2012. doi: 10.1007/BF03014574.

SIMÕES NETO, D.E. et al. Lançamento de novas variedades RB de cana-de-açúcar. Carpina: UFRPE, 2005. 28p. (UFRPE. Boletim técnico, 1)

YEH, N.; CHUNG, J.P. High-brightness LEDs - energy efficient lighting sources and their potential in door plant cultivation. Renewable and Sustainable Energy Reviews, v.13, n.8, p.2175-2180, 2009. Available from: <http://anakena.dcc.uchile. $\mathrm{cl} / \sim \mathrm{mnmonsal} / \mathrm{sdarticle} 03 . \mathrm{pdf}>$. Accessed: Oct. 28, 2012. doi: 10.1016/j.rser.2008.09.004. 